J. Dairy Sci. 99:9352-9352

http://dx.doi.org/10.3168/jds.2016-99-11-9352

(C) American Dairy Science Association ${ }^{\circledR}, 2016$.

\title{
Corrigendum to "Performance and amino acid utilization of early lactation dairy cows fed regular or reduced-fat dried distillers grains with solubles" (J. Dairy Sci. 93:3176-3191)
}

\section{K. Mjoun, K. F. Kalscheur, A. R. Hippen, and D. J. Schingoethe}

On page 3183, in Figure 1, the curves for the DDGC and RFDGS diets were incorrectly labeled. The figure and corrected caption (correction in bold) are shown below.

The authors regret the errors.
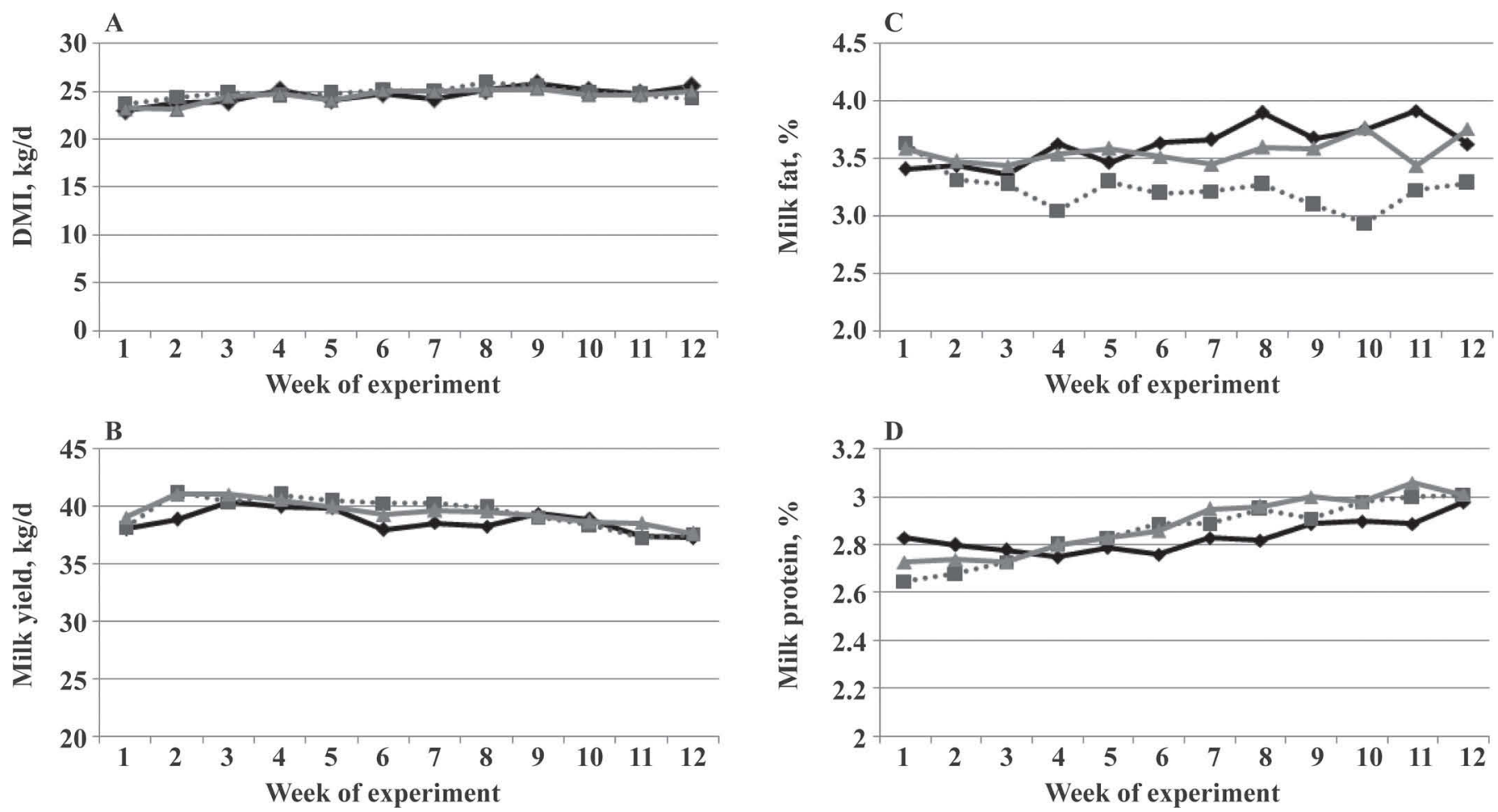

Figure 1. Dry matter intake, milk yield, and milk fat and milk protein by early lactation cows fed experimental diets: CON $=$ control diet containing a blend of soybean products $(--)$; DDGS = diet containing 22\% regular dried distillers grains with solubles (--and RFDGS = diet containing $\mathbf{2 0 \%}$ reduced-fat dried distillers grains with solubles $(-\boldsymbol{\Lambda}-)$. Effect of week was significant $(P<$ $0.05)$ for DMI, milk, and milk protein. There was a tendency for treatment $\times$ week for milk protein $(P=0.07)$.

\section{REFERENCES}

Mjoun, K., K. F. Kalscheur, A. R. Hippen, and D. J. Schingoethe. 2010. Performance and amino acid utilization of early lactation dairy cows fed regular or reduced-fat dried distillers grains with solubles. J. Dairy Sci. 93(7):3176-3191. 